\title{
THE “FLOATING HERSTORIES” SOUND PROJECT: A HELICAL COLLABORATIVE PROCESS
}

\author{
MAICA GUGOLATI \\ INSTITUTE OF AFRICAN WORLDS, SCHOOL OF ADVANCED STUDIES \\ IN THE SOCIAL SCIENCES (EHESS), PARIS
}

JORGE E. RAMÍREZ

CHAMPALIMAUD NEUROSCIENCE FOUNDATION, LISBON

\begin{abstract}
This article describes the sound project "Floating Herstories" in all its levels: from its conception and development, to its trial in the field on the island of Trinidad, in the Republic of Trinidad and Tobago, West Indies. Inspired by the childhood experience of hearing a shell on Caribbean seashores, this sound work uses seashells as the medium to transmit stories narrated by women authors from Trinidad. Co-written by two authors, this article describes the multidisciplinary construction of the project, involving the participation of the three narrators of the soundtrack. Following a situated heritage of storytelling, "Floating Herstories" aims to tell stories collected poetically by the Caribbean Sea. The trial with the finished prototype conveyed the reactions of the population in situ, from which we gathered some meanings concerning the experience of both telling a story and listening to one. On this basis, the article sets out some questions about the value of silence and selected sound in a familiar or estranged context.
\end{abstract}

KEYW ORD S : Trinidad \& Tobago; seashell; audio-electronics; orality; art-anthropology; morphology, women.

Trinidad and Tobago, West Indies.

A seashell is sounded in order to signal the beginning of a cricket match. ${ }^{\mathrm{T}}$

A seashell was sounded during the colonial period in the plantations in order to signal a fire emergency.

Seashells are used in divination ceremonies.

A seashell is an object of memory of all adults who remember themselves when they were children, playing at the beach on Sunday afternoons during limes with their families. ${ }^{2}$

I Cricket is the national sport of Trinidad and Tobago (West Indies).

2 The term lime is a creole word that locally means to hang out. 
This is an article about a sonic artistic project, made in collaboration between the two authors of this article, which has been tested in the field in the Caribbean country of Trinidad and Tobago. It explains the sound project and its theoretical foundations. It continues by describing the content and technical development of the devices. Finally, it ends with an ethnographic analysis of the project in situ, which took place during the summer of 2019 .

\section{THE PROJECT AND ITS ORIGINS}

The relations between art and anthropology have been analysed by many researchers: according to Arnd Schneider (2010; 2013; 2017), for example, there is a congruence between the act of making art and that of doing fieldwork. They are both productive, and explore and shape that which cannot be clearly understood. The entry of art into anthropology as a research practice, rather than a topic or object of research, generates a mutually transformative environment between the researcher, possible collaborators and the audience. It involves both an improvisatory endeavour (Ingold 2013) and a common suspension of disbelief out of which new forms of collaboration and participation may arise (Grimshaw and Ravetz 2015). However, there is an important difference between the roles of an artist and a social scientist: according to Bourdieu (1995: 139 cit. in Sasanka and Dev Nath 2019), the former acts in a belief of the uniqueness of the creator, while the latter, on the contrary, seeks to understand, explain and account for what s-he finds. This experimental project was neither a mise en scène, nor an installation practice; the intent was to propose a medium different from well-established qualitative interview methods and participant ethnography, one that could release the creative part of the researcher into a different approach of exchange with artistic communities and the general audience.

The idea of using seashells came out of a discussion with the Trinidadian contemporary artist Christopher Cozier, while we were brainstorming about a poetical way to aurally translate the concepts of insularity and transnationality. Thinking and working on sound, instead of the more common visual media, generates different questionings towards the notions of space and time and different opportunities for the audience to relate with them. Vision is historically associated with knowledge: from the Latin, videre, it is the source of the term "evidence" and "providence" (Le Breton 20I7). There is a factual rapidity and sense of reliability connected with vision that is expressed to an audience. On the contrary, the etymology of the Latin verb "to listen", ascultare, evokes the act of attentively lending the ear. It implies an attentive will and motion to the other that goes sonically, physically and emotionally close to the source of the listening; it functions as a connector and it requires attention and time. According to the artist Salomé Voegelin (20I0), the act of listening reminds the human being 
that $s /$ he inhabits their environment. Listening awakens an affective geography (25), which triggers the unseen action of the visual world: it attunes us to an experience of the unseen aurality.

The Cuban novelist Antonio Benítez-Rojo calls the population of the Caribbean, "People of the Sea" (200I: 28). This term refers explicitly to the notion that the inhabitants of Caribbean islands have a polyrhythmic connection that is able to overcome the geographical separation and distinct ethnic origins of their citizens. Trinidadians also use the expression "People of the Sea" to refer to the whole population of the island: those who come from European origins, as well as those of the Middle Passage (i.e. from the slave trade from the African continent), those of Kala Pani origin (literally from the Hindi "dark waters", identifying the East Indian population stemming from indentured labour from India) and the other multiple immigrations that encountered the First People, the native indigenous populations. In the name of this link with the sea, the shells in this project are interpreted as organic entities that, like the Caribbean people, are transitional.

In preparation for this project, the anthropologist contacted several of her closest friends, past informants of her $\mathrm{PhD}$ research. She asked them if they wanted to contribute to this project, while also participating in an act of joint creation. This process happened while she was in Europe, where she currently resides. The people who agreed to contribute to this journey are all women related to the art community. They were asked to use their own experiences and life as a starting point to think through what these seashells could talk about. They were asked what they would have loved to tell the metaphorical "sea" that could be heard by all coasts. They all decided, without having contact with each other, to create and record stories that deal with their matrilineage. This is why the term "herstories", used as the title of the project, has been coined. They are Floating Herstories, because the shells carry stories narrated by women about women; and they are floating because they deal with issues of transnationality and displacement that cross the ocean, just as a shell does. Metaphorically, through these devices, the herstories move and float in the up and down waves of the ocean, until they run aground on sandy beaches.

In Trinidad and Tobago, the spoken word holds a sense of doing as described in the performativity of speech postulated by John Austin (1962). This oral performance was at the root of the creation of Calypso music, which was born in Trinidad. This music genre is characterized by highly rhythmic vocals, wherein the singer replaces the role of the griot (West African storyteller). It was originally a masculine and patriarchal (Rohlehr 2004) musical practice. With this sound installation, the wish is to allow some intimate her-stories, silenced by the overwhelming abundance of patriarchal his-stories exemplified by the Calypso genre (Obolo 20II), to be heard. Proposing Herstories therefore challenges this secular heritage that is linked with storytelling. 
The act of telling stories in a post-plantation society intimately involves the notion of silence. During one trip to Barbados, a Trinidadian friend who had migrated there for professional reasons stated: "In plantation societies, silence is more talkative than words" (20I8). Her statement has accompanied this sound project in both a metaphorical and a theoretical way.

During another period of fieldwork in Trinidad, we came across an old expression that is still used: "If the river stones could talk." This saying denotes human relief at the impossibility of "talking" stones: because if stones were anthropomorphized, they could reveal intimate stories about usually illicit romantic encounters and affairs, gossiping (locally, $m a k o^{3}$ ) and 'bad talks' that took place during the period when women washed clothes along the rivers. Such activities were described as well during colonial times, when washerwomen and blanchisseuses ${ }^{4}$ washed and whitened their masters' clothes in the waters of the island's rivers.

This project also takes its inspiration from the creole mode of storytelling of "Crick-Crack". This practice in Trinidad has been recounted in Crick! Crack!: Trinidad and Tobago Folk Tales (1966), written by Eaulin Ashtin, and a visual example is shown in the seminal Martinican and French movie: Rue Cases Nègres (1983) by Euzhan Palcy. In this practice, the storytelling was performed through a verbal refrain that linked the storyteller and the audience. The storyteller announces that a story is about to be told by calling out "Crick!" to which the audience responds by shouting "Crack!", thus completing the phrase "crick crack". Through this refrain, the audience is not only listening to the story, but also affirming their presence in it. Hence, this practice of storytelling required a group performance in which the 'audience' participated with the narrator, thus creating a dialogic connection between the two that mixed them to the extent that they almost become one. This performative practice, which stems from West African heritage, has always been part of the cultural foundation of the Caribbean region. Nowadays, the expression "Crick Crack" is still used between adults and children when telling modernized stories. So, inspired by this regional cultural performativity, the project wishes to evoke a similar relationship between the shells and the listeners.

This sound project raises the connection between the etymology of "person" and "personhood" on the one hand, and the word "persona" and the verb "personare" on the other. This last term means to masquerade, to play a role, and thus comes close to the sense of autobiography. It is composed of "per" and "sonare": "to sound through", in reference to the sound made through the masks used in ancient Greek and Roman plays (Goffman [1959] 1969: 31; Hollis 1985; Mauss 1985). The shells in this sound work fulfil the same function as the ancient masks, which metaphorically created the persona, or the personage (the drama and social character), through a sound that

3 Mako: a local creole term meaning gossip.

4 The island of Trinidad still has a beach crossed by a river that is named Blanchisseuse. 
comes from a hole. According to this interpretation, the voices that are listened to from the shells should function as subjectivities that are heard, once attention is given to them by another person.

\section{FLOATING HERSTORIES AND ITS CONTENT}

The Floating Herstories sound project aims to immerse the audience in the most common childhood experience of being on a beach. By bending down and taking the shell to the ear, the audience enacts a memory journey. Instead of hearing the sound of the sea, the listener hears stories and sounds from Trinidad, recorded between 2018 and 2019 .

The sound content consists of storytelling. This is understood as the act of telling personal stories that have intimate significance and that communicate personal experiences, feelings and desires, allowing narrators to recognize how relevant these stories are (Portelli 2005). Moreover, storytelling, according to Helen Gilbert and Joanne Tompkins (1996), is a form of reconstructed fiction; in a postcolonial context, it serves to reposition history within and alongside settlers' stories. The act of remembering the stories and re-enacting them aurally is part of the process of reinvention of the narrators themselves (Muñoz 1999).

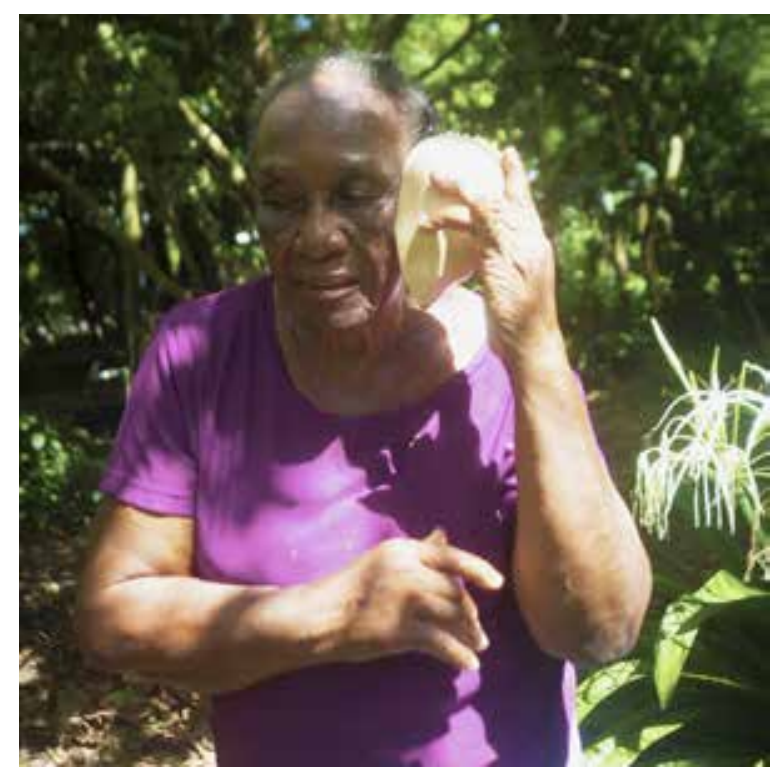

Vincenta Jessie de Archbold listens to a shell (2018) 
The shells poetically translate the stories carried by the sea. The project would like to be a poetic attempt to translate the sound of waves into human words and natural sounds.

The Floating Herstories project is the fruit of collective work between the two authors of this article and the three authors of the audio content: the writer Lesley-Ann Brown, the visual artist Tamara Tam-Cruickshank and the video maker Aletha Dale Mccullough. These last three were born or have family in Trinidad and Tobago.

\section{FLOATING HERSTORIES: TERMINOLOGY}

\section{- Floating}

Adjective from the verb to float: being buoyed up on water; moving from one place to another. This term gives a sense of insularity. The act of floating represents a $3^{\text {rd }}$ space (Bhabha 1996) in which the subject is neither underwater, nor in the air. While floating, an object follows waves and currents. For this project, the term corresponds metaphorically to a way of meandering between forces. Moreover, floating suggests a sensory metaphor of fluxes, flows and migrations, evoking the diaspora and the historical trade routes of which the country was part.

\section{- Herstories}

The authors collaborated digitally with the anthropologist at a distance, from three different locations: from Hawaii, where Aletha is located; from Trinidad, in the Caribbean region, where Tamara lives; and from Europe, where Lesley is based. The three authors have Trinidadian ancestors and/or were born in the country. All of them have lived or are still living abroad.

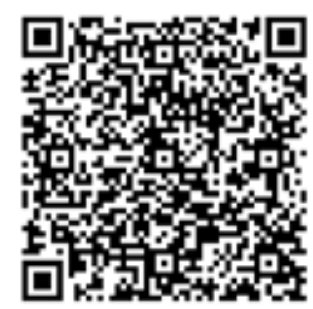

Floating Herstories

The herstories that are heard from the shells alternate with sounds of the natural and urban life of Trinidads. The audio starts with the sound of the waves of the ocean that bathe the coasts of Trinidad. It continues with a recording of a police siren in the capital, Port-of-Spain. Then come frogs, which sound like crickets, echoing the herstories told by Tamara of both her grandmothers' love for the sport with the same name (cricket), which is the national sport of Trinidad. The audio-project finishes with

5 Sound Composition Floating Herstories

https://rcin.org.pl/Content/I22007/Audio/WA308 I52207 P366 The-Floating-Herstor.mp3. 
Beethoven's Für Elise interpreted by Michael 'the Pan Doctor', a steelpan drum musician who lives and works on the island of Tobago. This last element of the soundtrack, in which Beethoven's piece is played on a steelpan, the pan-Caribbean musical instrument invented in Trinidad, suggests a symbolic dimension of self-exoticism and the European colonial construction of the tropics (Thompson 2007).

The herstories start with the text "Country, the map of liberation" by Lesley-Ann (2018). She begins with an Amerindian prayer whose geographical origins are unclear. It summarizes her feeling about the unknown possibility of tracing her ancestral heritage and the transnational construction of her identity.

The author touches on the issue of country, since this is the most frequently heard question for a transnational subject. She asks listeners which country they are from. Following a linguistic analysis of the meanings of the word "country", she continues with a synesthetic etymological analysis of the word, unveiling a poetic matrifocal dimension to its origins: "kunt", which refers to female genitals, and "tree", which the author connotes with a genealogical tree. Through her introduction, Lesley-Ann opens up the herstories to come from the other two authors.

The audio continues with Tamara's herstory. She starts by mentioning her autochthonous heritage from Carib descent. She wants to highlight the names of Trinbagonian locations that shaped her life and the lives of her family; to names derived from the Arawak language (such as Siparia and Chaguaramas), she adds those with Spanish origins (for the city of San Fernando), and others demonstrating English influence (represented by the Queen's Park Savannah). Moreover, she mentions her Chinese heritage, evoking and gently highlighting her family's silence about their African origins.

The third herstory is by Aletha-Dale. She recites a poem she wrote about and dedicated to her mother. She describes her mother's struggles in the modern era in Trinidad as an Indian woman of indentured labour descent, recounting how she decided to lead an autonomous life far from any masculine presence during the time of Black Power in the country. She describes her displacements from the countryside, where most Indian-descent Trinidadians were located during the colonial time, to the urban Creole capital, and then again when she decided to leave the country for the USA.

\section{THE CONCEPTION AND DEVELOPMENT OF THE “TALKING” SHELLS}

The seashells, commonly found on the seashore and on beaches, are left by sea snails (kingdom Animalia, phylum Mollusca, class Gastropoda), a large mollusc found ubiquitously in tropical waters. The shells are created by the animal in order to build a self-made confinement composed of deposits of calcium carbonate. This material 


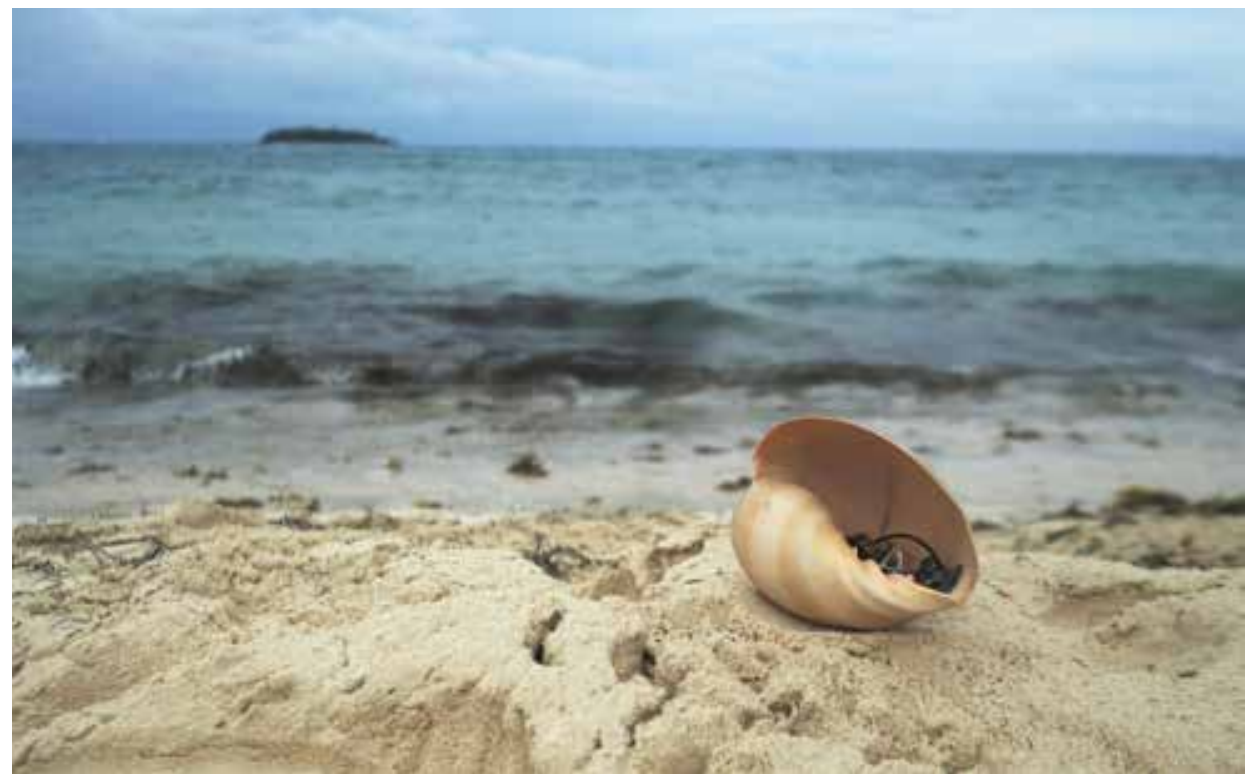

A "talking" shell device by the Caribbean Sea (2019)"

has the properties of human bones, which the animals can adjust to match their required hardness and density in order to become a protective barrier (Gutierrez et al. 2003). Thus, these shells provide a solid, moveable and growing shelter that accompanies the animals throughout their lives.

For this reason, the shell represents a testimony (a story) of the animal's life cycle, which is etched in the shell's cyclical structure. From ancient times until today, civilizations have questioned and used the stories the shells can "tell" on account of their shapes, sounds and compositions (Vermeij 1993). These never-aging stories and interpretations are ones that initiated and guided the technical development of the work.

While brainstorming together throughout the proto-engineering phase, we identified three conceptual templates that constituted the base of our creative framework:

\section{The shape template}

The initial template comes from the shell's raw form, which in the literature we collected has received a plethora of metaphorical interpretations. During this research, we found a peculiar phonetic connection between the word "aural", related to what the ear can

6 The electronic components have been pulled outside the shell for explicit illustration. 
hear, and the word "aurea" which means "gold" in Latin. Moreover, digging deeper in the biological and mathematical domains, we found additional connections.

First, we start with the association with "aurea". The spiral formed of ever-incrementing rings in seashells follows a proportion called the sectio aurea (Latin for "golden section"), a standardized aesthetic formalized by the ancient Greeks (Fletcher 2006). This proportion constituted a point of rupture in the ancient Greeks' rational understanding of nature, because it could not be formulated on the basis of their ideal mathematical framework. As a result, it was deemed irrational, almost magical: yet this proportion appears very often in many natural and human-made structures (Fletcher 2006; Stipancic and Matotek 20I0; Debnath 20II).

Long after the ancient Greeks, other mathematicians tried to reinterpret the magical realism of the sectio aurea, with the most salient example being Leonardo of Pisa (alias Fibonacci). He realized that a numerical sequence made of the sum of the two last consecutive numbers would produce this golden proportion (Debnath 20II), and as a result of this revelation, the origin of this proportion was made clear. So, whenever this proportion is present, it can be interpreted as the result of a linear, continuously progressing sequence (such as the numbers Fibonacci found). Interpreted in a geometrical sense for the shells, this proportion implies a story of an uninterrupted sequence of growth events, from the smallest ring to the biggest. This gentle and unencumbered growth story in the shell resembles a pristine, almost child-like story, without discontinuities or incoherencies. This simplicity of the story resonated with the shared appreciation of shells being an object of wonder. We also felt that childhood memories of being at the seaside with a shell reverberate with the story shaped by the shell itself.

In terms of the "aural" part, we were presented with a strong connection to this dimension when coming across a child that put a shell to their ear just to "hear de sea in de shell", as we were told, on one of the beaches in Trinidad.

In pursuing this link, we found that the human ear itself also has the shape of a spiral containing the sectio aurea, as explained above with regard to the seashells (Persaud and O'Leary 20I5). Metaphorically, we can imagine these two spirals talking to each other in the moment when a child puts an ear to a shell. What the child hears is the "conversation" between the two spirals that sounds like the murmur of the ocean. In reality, this sound comes from the acoustic filtering caused by the shell, which eliminates high-frequency content (Jiang and Smith 20I2). However, another valid interpretation is that what is heard in the shell is an absence of sound, or to put it in equivalent terms, the "sound of silence". Thus, what the child really hears is the auralization ${ }^{7}$ (Oliveros 2OII) of the silent, un-hearable conversation between their ear and the shell.

7 The term "auralization" is used by Pauline Oliveros to refer to the mental modeling that can evoke the perception of sound even when it is not physically present, similar to an image that is imagined. 
With this idea in mind, we wished to translate this "conversation" by giving it an understandable voice, so everyone could hear the stories that crisscross the sound of the ocean.

\section{The functional template}

The second template comes from the interaction between the shell and the animal it protects. The mollusc creates the shell with the purpose of being wilfully isolated, thus constructing both an internal habitat for itself and an outer surface that faces the environment. On the inside, the shell is smooth and polished (Barthelat et al., 2009), offering a comfortable and intimate passage between its inner and outer curves. On the outside, the shell functions as a barrier that protects from harm (Gutierrez et al., 2003). These two essences tell us about the shell's bivalency and about stories in general: both of them have a side that every outsider can see, but there is also an intimate side only accessible to the insider. This strongly resonated with a situation commonly encountered in anthropological fieldwork, where a story used for research also has a more intimate version that, from time to time, emerges spontaneously. We thought that these guarded stories could inhabit a place that suited them, maybe inside the sheltered space of a shell.

\section{The modular template}

For the last template, we looked at the acoustic features that shells seem to directly share with other existing structures. Once again, the most obvious connection we found sprang from their resemblance to the architectural legacy of the ancient Greeks. It turns out that late Hellenistic theatres were constructed using the same rationale as the molluscs apply to their shells. These theatres feature a series of sequential rings to seat the public (theatron) with incremental diameters that also follow the sectio aurea (Stipancic-Klaic and Matotek 20Io). In addition, the theatron was made of hard materials, such as marble (composed mainly of calcium carbonate, as are shells), that could endure wear and tear from both the weather and audiences. Moreover, the theatron was constructed with a smoothed inclination (koilon) in order for the sound to flow easily and reach every audience member (Chourmouziadou and Kang 2008). Therefore, both the seashells and the theatres have been optimized in a similar way, allowing the clear passage of beings and sounds, and probably, of both at the same time.

While searching for evidence of this modularity, we found that researchers have recently described the origin of the shell's sound by using modern methods to relate its shape to its acoustic resonance. Most shells have a specific set of resonant frequencies on the audible range, which can be excited by lip vibration and are transmitted omni-directionally (Pouraghdam 2016). In accordance with this, it is not surprising that many populations use shells as tools for music and communication (Schaefner 
1931). It was on the basis of this knowledge that we used the shell as an instrument to transmit our collected stories.

To sum up, the seashell is a playful teaser to everybody who has dwelt on the stories carved in its windings, through the ages and at all ages. We wanted to employ this fascination to convey oral stories grounded in the intimacy gained during fieldwork experience in anthropology. The bivalency of the shell's shape, and its acoustic properties, gave us the confidence to create a private scene for unheard stories to be (re) played to listeners.

In constructing our shell storyteller, we started our design process from the acquisition of the natural material. There are many types of different shells coming from numerous sea snail species. Amongst these, we aimed to select only shells with the following characteristics: (I) a wide inner compartment in which to fit the electronic components, (2) an aperture of a size big enough to fit tightly on the ear of a human listener, and (3) a light weight to facilitate transportation and handling. The only types of shell we found that fulfilled the chosen criteria were from the Voluptidae family, genus Melo, which unfortunately come from outside the Caribbean region (Buczkowski and Boron 2019; MolluscaBase 2019).

For the shells to be able to literally "tell" a story as we wanted, we needed to add some functions that they do not naturally possess. First, we separated its functionality into two main categories: the shell needed to be a speaker, and it needed only to "talk" when there was someone present to listen. For the first function, we used the DFPlayer (DFRobot, 20I9) as a playback device.

However, for the second function we needed to create a special detector capable of "feeling" the presence of a human ear: this detection function needed to be able to work in the confined space of the shell, and be both inaudible and out of the line of sight. After pondering possible detection mechanisms, we decided to use one based on the measurement of acoustic reverberation: through this phenomenon, the detectable volume of the sound increases when it bounces inside an enclosed space (Everest and Pohlmann 2009). This effect depends on an interaction between walls that receive and reflect the sound, such that they constructively overlap a part of the soundwaves, thus amplifying them.

This type of interaction in reverberation has been employed in a range of domains, not just that of engineering, to express a sense of repetitiveness, recurrence and a spread effect (Cambridge Dictionary 2019). It would be easy to think of this interaction as a sort of "dialogue", whereby a sound, idea or effect is transmitted and amplified within a group of walls, people or objects. However, this dialogical interpretation of reverberation is a piece of trickery. In a real dialogue, the communication is multi-directional, where every participant in the dialogue receives, interprets and elaborates a message (Merriam-Webster Dictionary 20I9). On the contrary, reverberation does not create new content: the message (or signal) is amplified just by the repetition of its copies 
that bounce from being to being. Therefore, what we ought to detect as the effect of reverberation inside the shell is just a bigger copy of the signal emitted by the shell.

As a result, we chose to use ultrasonic sound waves $(47 \mathrm{kHz})$ as the reverberation carrier signal. This was selected for two main reasons: first, the shell wall and human tissues (especially skull bone) act as reflectors at those frequencies (Culjat et al., 20IO; Pouraghdam 2016), and second, human hearing cannot perceive them (Everest and Pohlmann 2009). In the end, a custom-made electronic circuit was designed to do all the jobs: to emit the ultrasonic waves, to receive their reverberated version, to extract its amplitude and to trigger the playback device accordingly.

The final working state of the shell could be explained parsimoniously as follows. The shell responds to the presence of the listener as soon as the listener (or any hard object whatsoever) gets close to its aperture. This physical closeness and intimacy create a confinement of the volume of air inside the shell. This condition augments the volume of the unperceivable ultrasonic sound through reverberation, which makes it surpass a threshold of detectability in the circuit. It is as if the shell actively "asks" for a listener. Once the shell circuit "hears back" the presence of its new neighbour, it entrusts its (her)story to the listener through the playback speaker. As in a performance of Crick-Crack origin, the shell itself is a storyteller that plays to an audience after checking that it is being heard.

\section{THE “TALKING” SHELLS AND FLOATING HERSTORIES IN THE FIELD, AN ETHNOGRAPHIC PERSPECTIVE ${ }^{8}$}

During my doctoral fieldwork and in the experience of co-writing with some of my most important interlocutors, I was told that they were pleased and happy to continue long-term conversations, because they felt they were deconstructing their own thoughts and positionings while discussing them with me. The value of being asked to talk about issues, memories, personal opinions and life stories was desired and even requested by the interlocutors. The fact of personal exchange, wherein the interlocutors listened to and felt themselves talking about themselves, provided a sense of authorship of their own subjectivity (Gugolati 2018). The exercise of autobiography (Muñoz 1999) is a rehearsal of fiction, and becomes a field for self-production. The interlocutor, therefore, while talking about her/himself, exercises agency and becomes the subject of the narrated stories. Following this mutual joy of sharing, when I went to Trinidad in summer 2019 I proposed a different way to exchange with 
the people I am very close to. Since Floating Herstories was still at the prototype stage, I did not organize a formal sound installation, but asked some of my closest contacts to experience it and exchange ideas about it, in relation to both the content and the medium, in order to possibly improve the project. This happened informally, mainly at the homes of these interlocutors.

A year before, in 2018, the seashells were already functional, but without spoken content. In several limings, I brought with me a seashell with a very famous Calypso song (Mighty Shadow's Stranger 200I) recorded in order to see the reactions to the device itself. This was welcomed and accepted with great enjoyment: people were passing the "playing" seashell from one hand/ear to another, and as soon as people recognized the song (Mighty Shadow's Stranger from his 200I album), they would pass the shell to the next person that was waiting with intense curiosity. That year, I just shared the shell as a tool of discovery, rather than asking people to engage with the content. This I did the following year, 2019, when I went to Trinidad with Floating Herstories in the seashells.

This was the first time that the people I have been in contact with for almost a decade were asked to meet in order to discuss an already established issue. In comparison with previous meetings, as soon as I asked to change the rules between the speaker and the listener (themselves and myself), suggesting to them that we start an exchange with listening to the shells and only afterwards continuing with a discussion of it, the reactions were very different.

It was explicitly stated to me that the fact of listening for 9 minutes (the duration of the sound file) to people (female authors) they did not know, even though they shared the same nationality, was not felt to be as involving as talking about their own personal stories. I was offering and asking my interlocutors to listen to others' stories before talking about their own opinions. With this sound project, I asked for a radical change in interpersonal approach: instead of starting by asking interlocutors to talk about their points of view on specific issues, with me listening to them and afterwards discussing it together, I asked them to start by listening to the narrations of others expressed through the shell as the basis for the discussions. Faced with this different approach, most of the interlocutors reminded me that the role of listening to other people's stories was one that was meant to belong to me (as a researcher and as a foreign friend) whereas they were meant to explain themselves.

One person boldly told me that (I paraphrase): they (Trinidadians) do not want to listen to what they already know. In another conversation, another person told me that: "Trinis want just to talk and to listen to themselves while talking about themselves." One of the other answers I was given upon asking them to listen to this sound experience was that I should be "telling somebody else this story, because I already know it": in other words, these experiences were felt to be common to Caribbean 
people, and thus generated an aural sense of déjà-vu. The question of a lack of interest in listening to others' narrations is linked to an experience of estrangement. The most important issue for my interlocutors was to spread their voices and their narrations outside the community, as far as possible. I, as a foreign researcher, was embodying a double role: I was the incarnation of passing their stories formally to academic institutions or to media, and I was a trusted person and a friend with whom they could share who they are and give their critical analysis of their own society. But, with Floating Herstories and the seashells, I was asking them to start by listening to somebody else on topics they felt very familiar with, before creating new discussions.

In a country where a major part of the cultural tradition is based on orality and music (Huggings 2016), it was interesting for me to ask why this intimate performance of storytelling did not get a positive response. Sound is constantly present in the daily and sometimes nightly life of Trinbagonians. At home, for example, people usually have loud music coming from speakers or the TV playing loud, and family members carry on different conversations at the same time, selecting the sounds and the voices of the people they are talking to, without waiting for silence. At weekends, cars are parked on the beaches with their trunks open, in order to benefit from vibrations of the bass of the sound systems that are attached directly to the batteries of the cars. These examples of daily soundscapes show how the perception of sound, unlike that of other senses, cannot be voluntarily suspended. For example, sight can be temporarily stopped by closing the eyes, touch by withdrawing the hands, but sound continues to surround you, regardless of your will or intention (Le Breton 2017). In 20I4, I attended an open-air sound installation made by the artist Christopher Cozier entitled: Sound Systems. He closed off some streets of the neighbourhood of Woodbrook, in the capital Port-of-Spain, and installed several cars there that were completely full of sound systems. These cars performed a re-enactment of what happens in some mall parking lots, usually located at the centre of the island, during weekends. The sound coming from the high-volume speakers allowed observers to experience the Caribbean concept of "being consumed by the sound" (Shabazz 20II), where the sound of the music speakers is loud enough to move people physically as "sonic bodies" (Henriques 20II). With this installation, the artist imposed on the audience an experience of sound as it occurs in local daily life.

On the contrary, with Floating Herstories the purpose of the shells is the opposite. People need a quiet or silent place in order to hear the voices "of the shells". Their posture toward sound is different: they are not absorbed by it, but they have to wait for the sound to come out, through an interaction with the shells which requires physical proximity with them. What was proposed through the act of moving the shells to the ears was to experience an act of recollection, where silence and partial solitude are required in order to understand the voices and the meanings behind the 
narrations. This was definitely not like the previous trial I had made in 20I8, where people spent a few seconds each with the "sounding" shells, listening until the moment they recognized the well-known song in the shell. In almost all the feedback I received in the field, the fact of needing silence in order to hear the voices in the shells was deemed annoying by most of the interlocutors. The fact of taking time, in an informal and pretty silent environment, to listen to others' stories seemed like it was reducing the time available to talk together.

The opposite happened when I asked the family members of two of the herstories' narrators to listen to the shells. When I visited them, they expressed surprise in a positive way. The children of one narrator, for example, were extremely shocked to hear a shell "talking" as they got closer to it. When they heard the voice of their mother, they grew even more excited. They felt a dual experience: one wherein estrangement and novelty combined with proximity and familiarity. The husband of this same herstories' narrator was moved by her story, and fascinated by the engineering technique of the shell. He immediately shared his feeling of pleasure in experiencing, thanks to the project, a different intimate relationship with his wife and with the story she told. A similar situation occurred with another narrator's family members who were interested in the "talkative" seashells only when their cousin's herstory was being played. All of them were proud and very interested in the project (or its parts), because it related to people they knew intimately.

This audio project offers an experience of aural intimacy, of a type that listening requires. In listening, the listener needs to acknowledge what is being heard and to put aside time to reflect on it (Back 2007). This seems to occur mainly when the listener has an intimate relationship with the person behind the narrations. The intimacy of the act of listening required by the shells is therefore not just related to the individual relationship between the listener and the storytelling-s in the shell, but also to an intimacy that links members of a community already created by the content of the narrations.

On the contrary, when there is no previous intimate relationship with the people's accounts (and these accounts are not sung and collectively shared as it happens in music tracks), the act of listening is reserved by participants for listening to themselves when they tell their own stories and give their own points of view. In this case, the performativity of talking does not require an audience as an active listener distinct from oneself, but it evokes a self-referential act. Here, the relationship between sound and receiver functions like the shells of the prototype. The shells are self-referential devices that "talk" and "listen" without requiring any feedback from a listener other than that from itself. In sound, the person is immersed in what they are hearing. A person hears her/himself as if in a monologue. The perception of the self in sound is therefore embodied (Bataille 1994). 


\section{CONCLUSION}

This article deals with the creation, development and testing of the project Floating Herstories. It explained the steps of its collaborative creation of the project: starting from brainstorming, continuing with the development of the theoretical framework, followed by the design process of its expressive devices, and then advancing into the feedback and discussions collected from a field test.

This project opened avenues for a collaborative interpretation of soundscapes, by finding overlapping paths between anthropology, art, biology and engineering. These emergent links exemplify the trailing effect of the reverberation of ideas across disciplines, which forms a starting point for more thought-provoking dialogues between them. Some of the subjects raised by this project are related to the internal tension between listening and being listened to, and involve such issues as aural perception, (re)sounding silences, and reverberating intimacy.

Through this small field test, it has been possible to trace the evolution of the relationship between speech-voice and listening. From the seminal postcolonial question, "can the subaltern speak?", raised by Gayatri Spivak (1980), it is possible to move to an interpretation through the decolonial theoretical frame of Tuhiwai Smith (20I2), which would read: "does the non-subaltern want to hear the subaltern's speech?". The small experience of Floating Herstories might lead us to further nuance this question as: "How does the historical subalternized subject want to listen to subaltern stories different from their own?"

In the field test in Trinidad and Tobago, there were two kinds of interactions: one mainly displaying a lack of interest, expressed by those who stated their desire for and the importance of the chance to talk about themselves. For these interlocutors, the primary goal was the act of being both authors and subjects of their narrations, rather than listening to those of others. In a way, they behaved like "talking" shells themselves. By acting in a self/shell-centred manner, they actively seek a listener to share their stories, but they filter what does not resonate with them, until it might sound like the "silence" of the ocean. The second group, who took time to listen to the herstories and discuss them, were mainly connected with the authors, as family members or relatives. From this last observation, we conclude that there is a voluntary need to listen attentively to somebody else's stories when we are already emotionally connected with them, and thus where the act of listening reflects a kind of extended act of care.

In conclusion, this project opens the way to more ongoing collaborative experiments that stimulate new lines of questioning and research pathways. From an anthropological viewpoint, the impulse to talk without the complement of an equal (or even empathetic) motivation for listening is a compelling theme to follow up in present-day, for example in relation to facing new waves of different contemporary migrations. In a neurobiological frame, the distinction between a self/shell-centred automaton 
and a dialogic life-being is an upcoming hard problem deriving from the rapid progress of bio-inspired artificial intelligence. From an engineering perspective, there are still more design possibilities that could be added to the "talking" shells, such as a wireless communication system that could enable more contextual control of the playback and blur the line with its listener counterparts even further.

\section{BIBLIOGRAPHY}

A u s t in J. 1962. How to Do Things with Words. Cambridge: Harvard University Press.

B a c k L. 2007. The Art of Listening, Oxford: Berg Publishers.

$\mathrm{B}$ a r t h e 1 at F., R i m J. E., and E s p in o s a H.D. 2009. "A review on the structure and mechanical properties of mollusk shells - perspectives on synthetic biomimetic materials". In B. Bhushan and H. Fuchs (eds.) Applied Scanning Probe Methods XIII: Biomimetics and Industrial Applications.. Berlin: Springer, 17-44.

B a t a i 11 e G. 1994. Visions of Excess, selected writings 1927-1938. Minneapolis: University of Minnesota Press.

B e nít e z-R o j o A. 2001. "Introduction: the repeating island." In The Repeating Island, Durham: Duke University Press, 1-32.

B h a b h a H. K. 1996. "Culture's in-between”. In S. Hall and P. Du Gay (eds.), Questions of Cultural Identity. London: Sage Publications, 53-60.

B row n L-A. 2018. Decolonial Daughter. Letters from a Black Woman to Her European Son. London: Repeater.

B u c zk ow s ki A., and B or o n S. 2019. ViaNet Conchology. ViaNet Blog. URL: http://vianetconchology.com (accessed 28/11/2019)

C a m bridge D i c ti o n a ry, s.v. 2019. Exoticism Definition in English. URL: https://dictionary.cambridge.org/dictionary/english/exoticism (accessed 27/11/2019).

C a m bridge Di cti on ary, s.v. 2019. Reverberate Definition in English. URL: https://dictionary.cambridge.org/dictionary/english/reverberate. (accessed 28/11/2019).

Carrithers M., Collins S. and Lukes S. (eds.) The Category of the Person. Anthropology, Philosophy, History. Cambridge: Cambridge University Press, I-25.

Chourmouziadou K., and Kang J. 2008. "Acoustic evolution of ancient Greek and Roman theatres". Applied Acoustics 69, 514-529.

$\mathrm{Culj}$ a t M. O., Gold e n ber g D. and Tew a r i P., S ing h R. S. 20Io. "A review of tissue substitutes for ultrasound imaging". Ultrasound in Medicine \& Biology 36 (6), 86I-873.

D eb n a th L. 20II. "A short history of the Fibonacci and golden numbers with their applications". International Journal of Mathematical Education in Science and Technology 42 (3), 337-367.

D F R o b o t. 2019. DFPlayer Mini SKU DFRo299. Sensors \& Modules. URL: https://wiki.dfrobot.com/DFPlayer_Mini SKU DFRo292. (accessed 28/II/2019)

Everest F. A. and Pohlmann C. K. 2009. Master Handbook of Acoustics. New York: McGraw-Hill.

Fle t c h e r R. 2006. The Golden section. Nexus Network Journal 8 (I), 67-89.

Gilbert H. and To m pkins J. 1996. "Traditional enactments: ritual and carnival story telling." In Post-Colonial Drama. Theory, Practice, Politics, London: Routledge, 78-106; 126-137.

G offm a n E. [1959] 1969. La Vita Quotidiana come Rappresentazione. [The Presentation of Self in Everyday Life]. Translated by Margherita Ciacci, Bologna: Il Mulino. 
Gordon R. 2004. "I Lawa. The construction of masculinity in Trinidad and Tobago Calypso". In R. E. Reddock (ed.), Interrogating Caribbean Masculinities. Theoretical and Empirical Analyses. Kingston: University of the West Indies Press.

Gugolati M. 20I8. PhD Thesis. Pretty Mas', Visuality and Performance in Trinidad and Tobago's Contemporary Carnival, West Indies. EHESS Paris, PSL Universities, France.

Gutierrez J. L., Clive G. J., Stra yer D. L., and Iribarn e O. O. 2003. "Mollusks as ecosystem engineers: the role of shell production in aquatic habitats". Oikos IOI (I), 79-90.

Gri m s h aw A. and R a vet z A. 20I5. "The ethnographic turn - and after: a critical approach towards the realignment of art and anthropology". European Association of Social Anthropologists. Social Anthropology 23 (04), 4I8-434.

H e n r i q u e s J. 20II. Sonic Bodies, Reggae Sound Systems, Performance Techniques, and Ways of Knowing. New York: Continuum, I-I8.

Holl i s M. 1985. "Of masks and men”. In M. Carrithers, S. Collins and S. Lukes (eds) The Category of the Person, Anthropology Philosophy, History. Cambridge: Cambridge University Press, 217-233.

$\mathrm{Hugg}$ in s S. 2016. "The curators of cultural tradition: storytelling activities of the National Library of Trinidad and Tobago". Storytelling, Self, Society, I2 (I), Storytelling in Libraries, 66-80

J i a n g LT., S m i th J. R. 20I2. "Seashell effect. Pretouch sensing for robotic grasping". In 2012 IEEE International Conference on Robotics and Automation, 285I-2858. St Paul, MN, USA: IEEE. http://ieeexplore.ieee.org/document/6224985/, (accessed 29/II/2019)

Le B r e t o n D. 20I7. Sensing the World. An Anthropology of the Senses. New York: Bloomsbury.

Mauss M. 1985. "A category of the human mind: the notion of person; the notion of self". In M. Carrithers, S. Collins and S. Lukes (eds.), The Category of the Person: Anthropology, Philosophy, History. Cambridge: Cambridge University Press, $\mathrm{I}-25$.

Merriam-Webster Diction ary, s.v. 20I9. Note I. Dialectic: Logic Through Conversation. "Dialogue" Definition. https://www.merriam-webster.com/dictionary/dialogue\#note-I. (accessed I2/08/2019).

Mollu s c a B a s e. 20I9. MolluscaBase. http://www.molluscabase.org (accessed I8/10/2019).

Muñ o z J. E. 1999. Disidentifications. Queers of Color and the Performance of Politics, Minneapolis: University of Minnesota Press.

Oliveros P. 20Ir. "Auralizing in the Sonosphere: A Vocabulary for Inner Sound and Sounding". Journal of visual culture 10 (2), I62-I68.

Persa ud D., O ' Le a r y JP. 20I5. "Fibonacci series, golden proportions, and the human biology". Austin J Surg 2 (5). I066.

Po r tell i A. 2005. "A dialogical relationship. An approach to oral history". Expressions Annual I4, I-8.

Po u r a g d a m R. M. 20I6. PhD Thesis. Numerical Analysis and Experiments on the Acoustics of Conch Shells Modelled as Spiral Cavities, 81.

$\mathrm{S}$ a s a $\mathrm{nk}$ a P. and $\mathrm{P}$ a th a k D. N. 20I9. Intersections and implications: when anthropology, art practice, and art history converge. In Intersections of Contemporary Art, Anthropology and Art History in South Asia Decoding Visual Worlds, I-47.

$\mathrm{S} \mathrm{ch}$ a eff $\mathrm{ner}$ A. 193I. Projet d'une classification nouvelle des instruments de musique. Bulletin $d u$ Musée d'Ethnographie du Trocadéro I, 2I-25.

$\mathrm{S}$ chn e id e r A. and Wrigh t C. 20I0. Between Art and Anthropology: Contemporary Ethnographic Practice. New York: Berg.

$\mathrm{S}$ ch n e i d e r A. and Wrigh t C. 2013. Anthropology and art practice. New York: Bloomsbury.

$\mathrm{S}$ ch n e i d e r A. 2017. Alternative Art and Anthropology: Global Encounters. New York: Bloomsbury.

$\mathrm{S}$ p ivak G. 1988. Can the subaltern speak? In Cary Nelson and Lawrence Grossberg (eds) Marxism and the Interpretation of Culture, London: Macmillan.

St i p a n c i -K l a i c I., and M a t o t e k J. 20Io. The Golden Ratio. Kyoto: University of Osijek. 
Th o m p s o n K., 2007. An Eye for the Tropics: Tourism, Photography and Framing the Caribbean. Durham: Duke University Press.

Tu h iw a i S m it h L. 2012. Decolonizing Methodologies. Research and Indigenous People, London: Zed Books.

Ve r m e i j G.J. 1993. A Natural History of Shells. Princeton: Princeton University Press.

Vo e gelin S. 2010. Listening to Noise and Silence. Towards a Philosophy of Sound Art, New York: Bloomsbury.

Vo e g e l in S. 20I4. Sonic Possible Worlds. Hearing the Continuum of Sound. New York: Bloomsbury.

Movies:

1983. Rue Cases Nègres. Directed by Euzhan Palcy, FR.

20II. The Story of Lovers Rock. Directed by Menelik Shabazz. UK.

20II. Calypso Rose: Lioness of The Jungle. Directed by Pascale Obolo. FR.

\section{Authors' contacts:}

Maica Gugolati

Institute of African Worlds, School of Advanced Studies in the Social Sciences (EHESS), Paris, France

E-mail: maica.gugolati@gmail.com

ORCID: oooo-ooo2-o2 II-5579

Jorge E. Ramírez

Champalimaud Neuroscience Foundation, Lisbon, Portugal

E-mail:jerburi@gmail.com

ORCID: oooo-ooOI-7967-234I

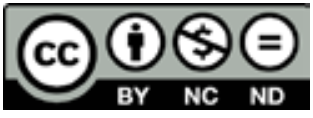


